Article

\title{
Daylight Performance of a Translucent Textile Membrane Roof with Thermal Insulation
}

\author{
Daniel Gürlich * (D), Amando Reber, Andreas Biesinger and Ursula Eicker \\ Research Centre for Sustainable Energy Technologies zafh.net, University of Applied Sciences Stuttgart, \\ Schellingstr. 24, 70174 Stuttgart, Germany; 71ream1msp@hft-stuttgart.de (A.R.); \\ andreas.biesinger@hft-stuttgart.de (A.B.); ursula.eicker@hft-stuttgart.de (U.E.) \\ * Correspondence: daniel.guerlich@posteo.de
}

Received: 29 July 2018; Accepted: 20 August 2018; Published: 24 August 2018

\begin{abstract}
Daylight usage in buildings improves visual comfort and lowers the final energy demand for artificial lighting. The question that always occurs is how much conservation can be achieved? New or rare materials and constructions have a lack of information about their application. Therefore, the current investigation quantifies the daylight and energy performance of a rare multi-layer textile membrane roof. A translucent, thermal insulation with a glass fibre fleece between the two roof membranes combines daylight usage and heating demand reduction. A sports hall built in 2017 is used as a case study building with $2300 \mathrm{~m}^{2}$ membrane roof surface. The optical properties of the roof construction were measured with a total visual light transmittance $\tau_{v}$ of $0.72 \%$ for a clean surface. A climate-based annual daylight modelling delivers daylight indicators for different construction scenarios. The results show that, in comparison to only one glass façade, the additional translucent and thermally insulated membrane roof construction increases the annual daylight autonomy $\left(\mathrm{DA}_{700}\right)$ from $0 \%$ to $1.5 \%$ and the continuous $\mathrm{DA}_{700}$ from $15 \%$ to $38 \%$. In the roof-covered areas of the sport field, this results in a 30\% reduction of the electricity demand for artificial lighting from $19.7 \mathrm{kWh}_{\mathrm{el}} / \mathrm{m}^{2} / \mathrm{a}$ to $13.8 \mathrm{kWh} \mathrm{el} / \mathrm{m}^{2} / \mathrm{a}$, when a dimming control is used. The study also found that the influence of the soiling of one layer decreases its light transmittance by a factor 0.81 . Two soiled layers lower $\tau_{\mathrm{v}}$ by a factor of 0.66 to $0.47 \%$. This increases the electricity demand for lighting by only $12 \%$. The results should be very valuable as a comparison and benchmark for planners and future buildings of a similar type.
\end{abstract}

Keywords: translucent textile membrane roof; climate-based daylight modelling; daylight performance; energy conservation; translucent thermal insulation; multi-layer membrane

\section{Introduction}

The construction and materials of a building have a huge influence on its physical interaction with the environment and the required technical effort to reach the required indoor acoustics, air quality, visual and thermal comfort states. Passive functional components show less life cycle financial and environmental cost and need less maintenance than active systems. The drawback of less control of passive components can be compensated with adequate planning, sizing and backup systems.

In this context, passive daylight usage in buildings improves visual comfort and lowers the energy demand for artificial lighting. However, how much conservation can actually be achieved? New or rare materials and constructions often lack information about their application. Therefore, the current work investigated the daylight performance of a multi-layer textile membrane roof with a size of $2300 \mathrm{~m}^{2}$ on top of a sports hall (Figure 1). 


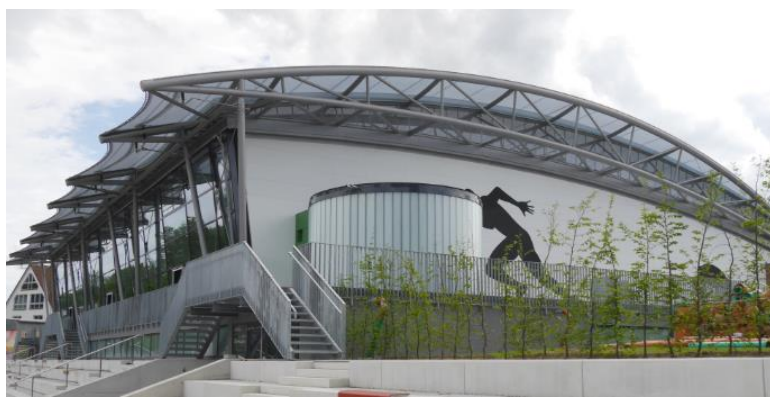

(a) glass façade on the north-east side

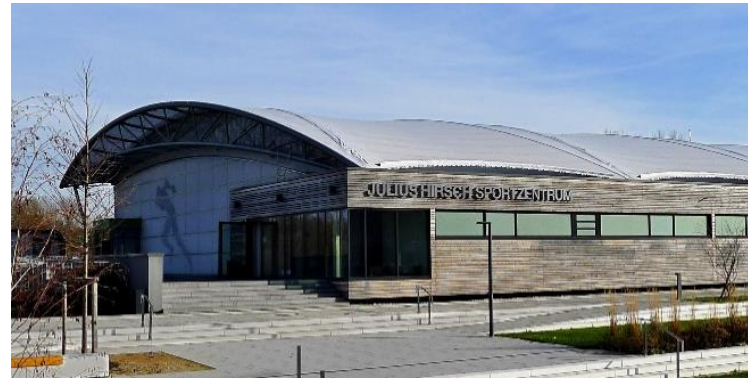

(b) attachment with wooden façade

Figure 1. Photographs of the case study building from: (a) north; and (b) west.

As the authors of this study found few articles about energy data related to sport buildings in general and especially none on the visual influence of membrane constructions, the literature review mainly refers to office buildings and other translucent materials. Other researchers, e.g., Haase et al. (2011) [1], made the same observation about membrane constructions. With the term "membranes", we refer to textile membranes with a woven fabric in distinction to foils. Some sport buildings with multi-layer membrane roofs have been built in the last years, but with very little available public information. There are for example the "Odate Jukai Dome Park" in Japan, the "Kurklinik Masserberg" in Germany (no translucency) and the "Dedmon Athletic Center in Radford" in USA (see Table 1).

Table 1. Optical properties of other multilayer membrane roofs.

\begin{tabular}{ccc}
\hline Site & Light Transmittance $\boldsymbol{\tau}_{\mathbf{v}}$ & U-Value [W/m $\left.\mathbf{m}^{2} / \mathbf{K}\right]$ \\
\hline Odate Jukai Dome Park [2] & $8 \%$ & no insulation \\
ZAE Würzburg Technikum [3] & $3 \%$ & 1 \\
University Sport centre Radford [4] & $3.5 \%$ & 0.47 \\
Olympia swimming hall Munich [4] & $1.5 \%$ & 0.42 \\
\hline
\end{tabular}

Concerning energy performance, the electricity consumption to supply indoor illuminance needs has a relevant part in the total energy consumption of buildings. A report [5] based on simulations from the institute for housing and environment in Germany relates 34\% of the primary energy (PE) demand $\mathrm{Q}_{\mathrm{PE}}$ in a standard office building to artificial lighting (al). This corresponds to an electricity demand for artificial lighting $\left(\mathrm{Q}_{\mathrm{el}, \mathrm{al}}\right)$ of $27.6 \mathrm{kWh} \mathrm{el} / \mathrm{m}^{2}$ tfa for low efficiency lamps $\left(5.4 \mathrm{~W}_{\mathrm{el}} / \mathrm{m}^{2} / 100 \mathrm{~lx}\right)$ or $35 \%$ of the total electrical energy demand $Q_{\mathrm{el}, \text { tot }}$. The target indoor illuminance in that report is assumed to be $300 \mathrm{~lx}$. This amount can be decreased by $87 \%$ to $3.4 \mathrm{kWh} \mathrm{el}_{\mathrm{el}} / \mathrm{m}^{2}{ }_{\text {tfa }}$ using high-efficient fluorescent lamps $\left(2.5 \mathrm{~W}_{\mathrm{el}} / \mathrm{m}^{2} / 100 \mathrm{~lx}\right)$, a daylight sensitive lighting control and a strategy allowing different illuminance levels in the room and individual working space lights. Then, the workstations are illuminated with $500 \mathrm{~lx}$ and all other areas with $220 \mathrm{~lx}$. The PE/ $\mathrm{Q}_{\mathrm{el}}$ demand for artificial lighting in such a high efficiency building is then $15 \% / 23 \%$ of the annual energy demand. In the commercial building sector of the U.S.A., in 2003/2012, artificial lighting accounts for $21 \% / 10 \%$ of the measured total site energy consumption and $38 \% / 17 \%$ of the $Q_{\mathrm{el}, \text { tot }}$ consumption [6]. A Swiss monitoring study in 128 office buildings reports a $25 \%$ share in the $Q_{e l, t o t}$ consumption during 2005-2007. The report confirms the U.S.A. trend of the high exploitation of efficiency potentials in lighting technology.

\subsection{Energy Consumption in Sport Buildings}

The authors of the current article found very little information about the detailed composition of the energy consumption of sport buildings. As lighting is the focus of this article, heating energy, e.g., from Beusker et al. [7], is not of interest. Two studies from 2009 and 2005 report monitoring values of the arithmetic mean for the total electricity consumption $Q_{\text {el,tot }}$ in German "dry" sport halls of 
$32 \mathrm{kWh}$ el $/ \mathrm{m}^{2} / \mathrm{a}$ (sample size 1365 [8]) and $50 \mathrm{kWh}$ el $/ \mathrm{m}^{2} /$ a (sample size 90 [9]). A UK report from 2001 [10] states as typical mean $Q_{\mathrm{el}, \text { tot }}$ for a local dry sports centre $105 \mathrm{kWh}$ el $/ \mathrm{m}^{2} / \mathrm{a}$.

\subsection{Lighting Systems and Conservations}

When speaking about "savings" or "conservations", a crucial but often ambiguously mentioned issue is the reference or base case that any scenario relates to. In addition, the real consumption is highly sensitive to boundary conditions such as neighbouring buildings, availability of solar radiation, target illuminance, geometries, user behaviour, equipment specifications or correct sizing. Hence, there is a high variation between different buildings and comparisons should be taken with care. Consequently, electric energy savings for lighting determined via measurements or calculation show a very large range of variation between $11 \%$ and $94 \%$ [11]. Some correlations try to cover all relevant influences and offer methods to estimate energy savings (e.g., Krarti et al. [12] and Ihm et al. [13]). Lowry [11] criticized that savings caused by automatic controls are overestimated in many cases because of choosing a non-adequate reference scenario with an insufficient user behaviour profile for manual on/off control. He also suggested as a key performance indicator to focus on absolute energy metrics instead of percentage savings. The authors of the current article strongly support these suggested methods and try to give absolute energy values and clear reference scenarios.

Besides the environmental and financial costs of the energy demand for artificial lighting, visual comfort and health aspects are also in favour of natural daylight $[14,15]$. In sunlit situations, the natural daylight often has to be blocked to prohibit glare and overheating. Beside transparent windows with shelves and reflecting blinds [16], other constructions exist such as translucent wall materials or waveguide systems especially to transport daylight also to façade distant spaces.

\subsubsection{Materials}

Translucent materials can help to reduce glare risk with an increased indoor daylight availability. However, glare remains a relevant risk. Matusiak [17] investigated the human glare sensing in the high latitudes of Norway with experiments. Her results are that a completely translucent aerogel façade in direct sunlight orientation with a light transmittance $\tau_{\mathrm{v}}$ of $29 \%$ still causes intolerable glare in sunlit periods.

A numerical study from Pagliolico et al. [18] in Turin applied partly translucent interior walls with glass splinters in the concrete $\left(\tau_{\mathrm{v}} 29 \%\right)$. The target of the photosensitive dimming control was $500 \mathrm{~lx}$. Compared to opaque interior walls, the $\mathrm{Q}_{\mathrm{el}, \mathrm{al}}$ decreases from 11.3 to $10.0 \mathrm{kWh}_{\mathrm{el}} / \mathrm{m}^{2} / \mathrm{a}$ in rooms with adjacent south oriented outside wall (with movable blinds) and from 6.3 to $5.0 \mathrm{kWh}_{\mathrm{el}} / \mathrm{m}^{2} / \mathrm{a}$ for north orientation.

In New York, a multipurpose, seven-storey building with a translucent marble envelope was investigated by Rosso et al. [19]. A Colour Rendering Index (CRI) of 86 is measured. Simulations under an indefinite control reveal a decrease in the $Q_{e l, a l}$ from 18 to $16 \mathrm{kWh}$ el $/ \mathrm{m}^{2} / \mathrm{a}(11 \%$ savings) for a translucent marble façade $\left(\tau_{\mathrm{v}} 7 \%\right)$ compared to an opaque one. Furthermore, the high solar reflectance of $58 \%$ for the marble reduces the demand of energy for cooling by $10 \%$, when compared to more traditional cement-based façades with solar reflectance of 30\%. The target illuminances ranged from 150 to $300 \mathrm{~lx}$.

A translucent wall with silica aerogel and PCM material has been investigated experimentally and numerically in a laboratory by Souayfane et al. [20]. They focus on the thermal behaviour.

Ahuja et al. [21] evaluated the monetary savings in energy consumption for heating, cooling and lighting of an interesting translucent concrete wall system in Berkeley. Unfortunately, the reference was not a realistic scenario with a standard window wall but a completely opaque room. The insulated concrete panels were fabricated with embedded optical fibres with different fibre ratios for light transmission. The fibres penetrated all wall layers, namely concrete, Extruded Polystyrene (XPS) insulation and the final drywall. With a probabilistic manual on/off switching behaviour of the occupants, they found an optimum financial cost reduction of $18 \%$ related to a completely opaque room. 
Optical fibres can also be combined with solar concentrators for a building daylighting system (waveguides). They can deliver sunlight deep into the interior rooms of a building [22,23]. This technology allows supplying rooms without outside connection with natural daylight. To distribute the collected light, conventional light fittings can be used. However, the operating distance of such systems is limited. With increasing length of the optical fibres, the wavelength between 720 and $780 \mathrm{~nm}$ in the visible wavelength range will be lost. That causes a blue shift which leads to optically uncomfortableness [24].

\subsubsection{Lighting Control}

As with all automation systems, for the lighting control system, the control strategy and control parameters influence the result tremendously. Different control types are:

- Manually operated on/off (not automatized).

- Time scheduled on/off.

- Occupancy sensitive on/off.

- Daylight sensitive with: (i) dimming; or (ii) stepped.

Hybrids between these types are possible. A daylight sensitive control can reduce the $Q_{\mathrm{el}, \mathrm{al}}$ by $75 \%$ with a simple time schedule as a reference [25]. Comparing dimming and stepped daylight sensitive controls, dimming is only advantageous from an energetic point of view for low sunlit locations or room geometries $[25,26]$. Then, the part load can be effectively used and only few time periods with the (unwanted) minimum residual load of dimming lightings occur. On the other hand, dimming appears more appealing for human sensation because of the more continuous changings.

Field experiments measuring illuminance in an atrium office building in Hong Kong indicate electricity savings for dimming control compared to opaque walls of 59-75\% [27]. Roisin et al. [28] investigated the potential energy savings in a virtual office room with occupancy or daylight sensitive control in three European cities (Stockholm, Brussels and Athens). The reference has the same geometry but a different control with time scheduled on/off: 45-61\% of the electric energy can be saved with dimming and $11 \%$ with occupancy on/off control. The façade orientation played a minor role in the order of $4 \%$ in the worst case of Stockholm. A field study [29] in a 51-storey office building in New York revealed a $20 \%$ reduction of $Q_{\mathrm{el}, \text { al }}$ for dimming control relative to an occupancy based control.

Going into more detail is out of the scope of the current article. In the case study, building a dimming control is realized as described in Section 2.1.

\subsection{Membrane Roofs}

The advantages of textile membrane roofs are their low weight and long covering ranges. Furthermore, they appear very aesthetic with their unusual and soft shapes. A sophisticated collection of realized membrane buildings can be found in a report by Haase et al. [1] in German language. Many aspects of these special tensile roof constructions are of importance, for example the wind loadings on their unusual shapes [30] or the acoustic behaviour [31]. However, this is out of the scope of the current article. Concerning the optical properties, Haase et al. [1] measured a light transmittance $\tau$ of $3.7 \%$ for a single layer of a PVC coated Polyester (PES) tensile membrane and $1.1 \%$ for a double layer with air gap. An overview of some example buildings with membrane roofs and their properties is given in Table 1. The multipurpose hall "Odate Jukai Dome Park" (Japan) with two layers of PTFE coated glass fibre textile shows a light transmittance of $8 \%$ [2]. Insulated and translucent multilayer constructions are also realised: The "ZAE Würzburg Technikum" building (Würzburg, Germany) with $10 \mathrm{~cm}$ translucent glass fibre insulation shows a U-value of $1 \mathrm{~W} / \mathrm{m}^{2} \mathrm{~K}$ and a $\tau$ of $3 \%$ [3]. The University Sport centre Radford (VA, USA) with an aerogel insulation and glass fibre membrane shows a $\tau$ of $3.5 \%$ and a U-value of $0.47 \mathrm{~W} / \mathrm{m}^{2} / \mathrm{K}$ [4]. The Olympia swimming hall Munich (Germany) with a $7 \mathrm{~cm}$ PES fleece insulation has a U-value of $0.42 \mathrm{~W} / \mathrm{m}^{2} / \mathrm{K}$ and a $\tau$ of $1.5 \%$ [4]. 


\section{Materials and Methods}

In this section, we present first the case study building's properties and geometry and then optical measurements. The annual daylight simulations with the different scenarios are described last. They yield the key performance indicators of daylight use and electricity consumption.

\subsection{Case Study Building}

The community gym "Julius-Hirsch-Sportzentrum" is located $288 \mathrm{~m}$ above sea level at 49.482 latitude and 10.988 longitude in the German municipality of Fürth [32]. The sport arena is intended to host one indoor soccer/hand ball/basketball match or three small spaces for school sports.

The building has a glass façade on the northeast side with the so-called indoor "balcony", a $45 \mathrm{~m} \times 27 \mathrm{~m}$ indoor field, changing rooms below the balcony and in the integrated attachment with the wooden façade. Figure 1 shows photos from the outside and a schematic top view is presented in Figure 2a. The rooms are arranged throughout the basement and ground floor while the sport field is located at the subterranean level of the basement, as shown in Figure 2b. The membrane roof spans the field and partly the secondary rooms. From an architectural point of view, the shape of the roof reminds of a sprinter on the starting block while the white membrane represents sportswear [33]. The light weight impression of the building appears adequate to the dynamic activities inside [33].

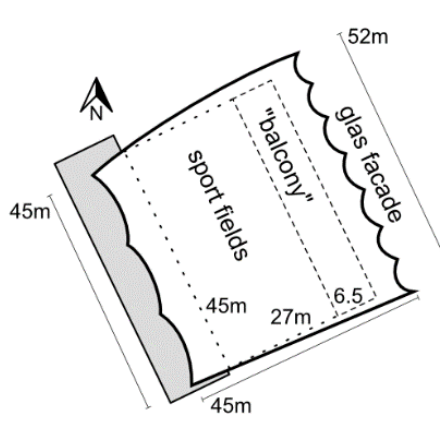

(a) Top view scheme

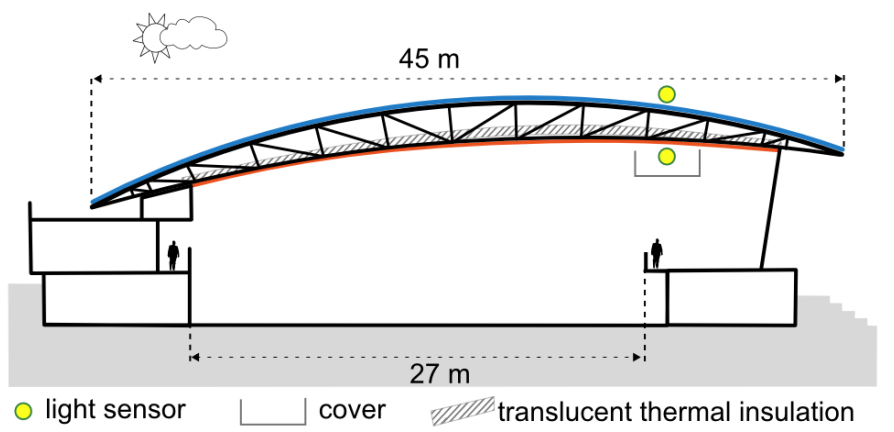

(b) Elevation from south direction

Figure 2. (a) Scheme of the top view; and (b) elevation from south direction of the complete building. The sensor positions of the short time measurements of the illuminance are indicated.

The overall heat transfer coefficient (U-value) is $0.23 \mathrm{~W} / \mathrm{m}^{2} / \mathrm{K}$ for the opaque and $1.6 \mathrm{~W} / \mathrm{m}^{2} / \mathrm{K}$ for transparent envelope components (from the certificate EnEV 2007, more details in Table A1). The total primary energy demand according to EnEV 2009 is calculated as $129 \mathrm{kWh} / \mathrm{m}^{2}$. Further description about hygrothermal simulations of the roof construction and general information about the project can be found in Cremers et al. (2016) [34]. Details about the roof construction follow in the next subsection.

\subsubsection{Roof Construction}

The scheme of the layer construction of the roof can be found in Figure 3a. It consists of an outer membrane $(\mathrm{OM})$ as weather protection, a $0.5-2.5 \mathrm{~m}$ air space, a thin cover foil as humidity barrier, a thermal insulation, a small $4 \mathrm{~cm}$ air gap and the inner membrane (IM). The OM is walkable. A photography of the membrane interspace is shown in Figure 3b. A maintenance gangplank on the right side, the underside of the outer membrane at the top part of the image and the cover foil at the bottom part can be seen. The relevant properties of the roof construction and the glass of the façade are presented in Table 2. Most information was taken from the company datasheets. The total transmittance was measured as described in Section 2.2. 


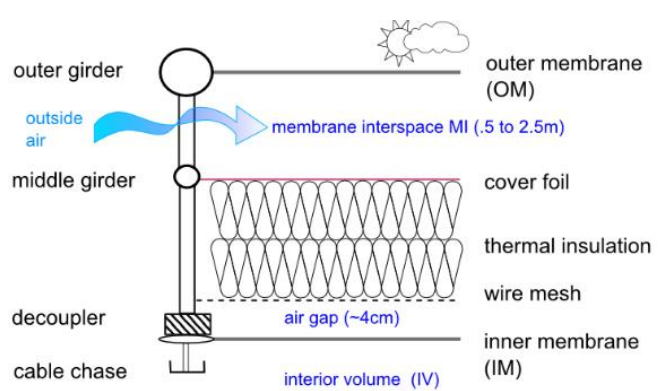

(a) scheme is not proportional

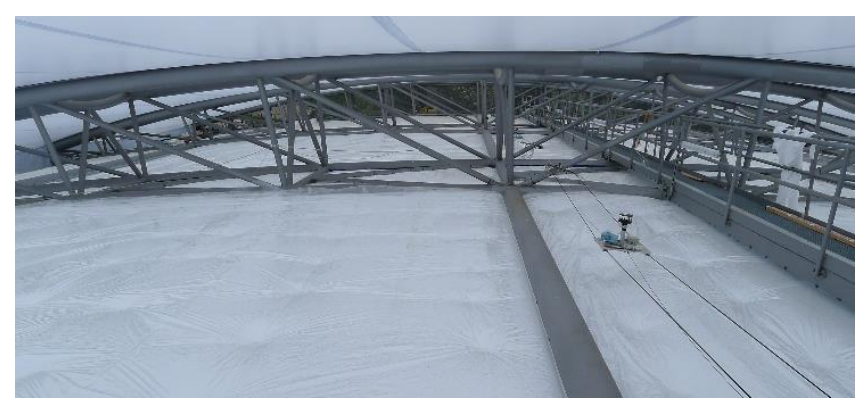

(b)

Figure 3. (a) Side view scheme of the roof layer construction; and (b) photograph of the membrane interspace. A monitoring platform for other measurements is visible on the two ropes on the right-hand side of the image.

Table 2. Material properties of the building's non-opaque components.

\begin{tabular}{|c|c|c|c|}
\hline Component & Product & Property & Value \\
\hline Glass façade & Insulated triple glazing & Light transmittance $\tau_{\mathrm{v}}$ & $60 \%$ \\
\hline Outer membrane & $\begin{array}{c}\text { Précontraint } 1202 \text { T2 } 2399 \text { high translucency type, } \\
\text { Serge Ferrari S.A.S }\end{array}$ & $\begin{array}{l}\text { Fabric material/Top } \\
\text { bottom coating } \\
\text { Top/bottom varnish } \\
\text { Light transmittance }{ }^{1} \tau_{\mathrm{v}} \\
\text { Light transmittance }{ }^{2} \tau_{\mathrm{v}} \\
\text { Light transmittance }{ }^{3} \tau_{\mathrm{v}}\end{array}$ & $\begin{array}{c}\text { Polyester/PVC } \\
\text { Polyvinylidenfluorid (PVDF) } \\
18 \% \\
16 \% \\
25 \%\end{array}$ \\
\hline Cover foil & Hostaphan ${ }^{\circledR}$ RUF, Mitsubishi polyester film GmbH & Material & Polyethylenterephthalat (PET) \\
\hline $\begin{array}{c}\text { Thermal insulation } \\
\text { roof }\end{array}$ & TIMax GL-PlusF Wacotech GmbH \& Co.KG & $\begin{array}{c}\text { Material } \\
\text { Thermal conductivity } \\
\text { Thickness } \\
\text { U-value }\end{array}$ & $\begin{array}{c}\text { Glass wool } \\
\text { ca. } 0,1 \mathrm{~W} / \mathrm{m} / \mathrm{K} \\
40 \mathrm{~cm} \\
0.25 \mathrm{~W} / \mathrm{m}^{2} / \mathrm{K}\end{array}$ \\
\hline Inner membrane & $\begin{array}{c}\text { Précontraint } 1002 \text { S2 3399, high translucency type, } \\
\text { Serge Ferrari S.A.S }\end{array}$ & $\begin{array}{c}\text { Fabric material/Top } \\
\text { bottom coating } \\
\text { Top/bottom varnish } \\
\text { Solar transmittance }{ }^{2} \mathrm{~T}_{\mathrm{S}} \\
\text { Light transmittance }{ }^{2} \tau_{\mathrm{v}}\end{array}$ & $\begin{array}{c}\text { Polyester/PVC } \\
\text { PVDF } \\
19 \% \\
16 \%\end{array}$ \\
\hline Total roof construction & & Light transmittance ${ }^{1} \tau_{\mathrm{v}}$ & ca. $0.72 \%{ }^{4}$ clean, $0.47 \%{ }^{1}$ soiled \\
\hline
\end{tabular}

\subsubsection{Lighting System}

The lighting installations in the main hall have a total electrical power of $10.4 \mathrm{~kW}$ and a luminous flux of $1830 \mathrm{k} \mathrm{lm}$. This refers to Light Groups 1-4 in the simulation. They are listed in Table 3. The dynamic dimming control design aims to an illuminance on the ground of $700 \mathrm{~lx}$. Three levels of 300,500 and 700 lx can be set manually to override the automatic.

Table 3. Technical data of the realized lighting inside the main hall.

\begin{tabular}{ccc}
\hline $\begin{array}{c}\text { Properties of one light element } \\
16,500\end{array}$ & $\begin{array}{l}\text { W electricity consumption apiece } \\
\text { lm luminous flux apiece }\end{array}$ & $\begin{array}{c}\text { A hall }: \text { area of the sport fields and platform } \\
\text { refers to the foot print area of the main hall } \\
1507 \mathrm{~m}^{2}\end{array}$ \\
m length apiece & Design illuminance on the floor: $700 \mathrm{~lx}$ \\
\hline 111 & pieces in total & $(10.4 \mathrm{~kW}$ total $)$ \\
\hline 6.9 & $\mathrm{~W} / \mathrm{m}^{2}$ electrical power $/ \mathrm{A}_{\text {hall }}$ & $(1832 \mathrm{klm}$ total $)$ \\
\hline 1215 & $\mathrm{~lm} / \mathrm{m}^{2}$ luminous flux $/ \mathrm{A}_{\text {hall }}$ &
\end{tabular}

\subsection{Optical Measurements}

To calculate the (visual) light transmittance $\tau_{\mathrm{v}}$ (DIN EN 410:2011-04), measurements of the (visual) illuminance $\mathrm{E}_{\mathrm{v}}$ based on EN 14500:2008 were carried out. A spectrometer "GL Spectis 1.0 Touch" from 
"GL Optic Lichtmesstechnik GmbH" was used as measuring equipment. The spatial positions of the sensor were $5 \mathrm{~cm}$ under the inner membrane $\left(\mathrm{E}_{\mathrm{V}, \mathrm{IM}}\right)$ and vertically directly above the position on top of the outer membrane. $\mathrm{E}_{\mathrm{v}, \mathrm{OM}}$ equals the ambient conditions in the membrane plane (Figure $2 \mathrm{~b}$ ). A cover protects the bottom measurement under the IM from insolation through the glass façade. Multiple measurements were recorded (Table 4 ) and led to a (visual) light transmittance $\tau_{\mathrm{v}}$ of $0.47 \%$ with soiling on top of the $\mathrm{OM}$ as well as on the cover foil. The roof construction was at the time of the measurement two years old.

Table 4. Measurement of the illuminance for the (visual) light transmittance $\tau_{\mathrm{v}}$.

\begin{tabular}{ccccccccc}
\hline \multirow{2}{*}{ Year 2018 } & $\mathbf{G}_{\text {glob,OM }}$ & $\mathbf{G}_{\text {glob,IM }}$ & $\mathbf{E}_{\mathbf{v}, \mathbf{O M}}$ & $\mathbf{E}_{\mathbf{v}, \mathbf{I M}}$ & $\tau_{\text {tot }}$ & $\boldsymbol{\tau}_{\mathbf{v}}$ & $\mathbf{C C T}_{\mathbf{v}, \mathbf{O M}}$ & $\mathbf{C C T}_{\mathbf{v}, \mathbf{I M}}$ \\
\cline { 2 - 8 } & {$\left[\mathbf{W} / \mathbf{m}^{\mathbf{2}}\right]$} & {$\left[\mathbf{W} / \mathbf{m}^{\mathbf{2}}\right]$} & {$[\mathbf{l x}]$} & {$[\mathbf{l x}]$} & {$[\%]$} & {$[\%]$} & {$[\mathbf{K}]$} & {$[\mathbf{K}]$} \\
\hline 8 May 10:38 & 431 & 2.52 & 89100 & 416 & 0.58 & 0.47 & 5720 & 7560 \\
8 May 10:39 & 432 & 2.55 & 89300 & 420 & 0.59 & 0.47 & 5730 & 7570 \\
8 May 10:39 & 432 & 2.57 & 89100 & 425 & 0.60 & 0.48 & 5730 & 7550 \\
8 May 10:40 & 432 & 2.56 & 89100 & 422 & 0.59 & 0.47 & 5720 & 7560 \\
\hline average & & & & & 0.59 & 0.47 & 5725 & 7560 \\
\hline
\end{tabular}

With the same measuring device, the illuminance above and below the OM was recorded at two different positions: around a cleaned area of $1 \mathrm{~m}^{2}$ and around a soiled area untouched for two years. Therewith, the transmittance $\tau_{\mathrm{v}}$ of only the clean OM was calculated to $18 \%$ and the soiled OM to $14.6 \%$. Hence, a decrease of the transmittance through one layer by a factor 0.81 was caused by the soiling. As the layer in between the cover foils also gets soiled by dust and pollen, we estimated the clean transmittance from the complete roof construction as $0.72 \%\left(0.47 \%\right.$ divided by $\left.0.81^{2}=0.656\right)$. Additionally, the daylight factor was measured as $0.83 \%$. The daylight factor represents the percentage of the outdoor light (illuminance in lx) under overcast skies that is available indoors on the horizontal plane in the occupant area.

\subsection{Simulation}

\subsubsection{D Model}

The geometry of the sports hall was simplified for the simulation and built in SketchUp Pro 2018. The hall itself was shown as a hall floor and a platform behind a single glass front, which consists of joined single windows. Adjacent rooms and the supporting structure were not mapped for the light simulation process. The roof was designed as a translucent membrane roof. Table A3 in Appendix A presents the material definition file of DIVA for the translucent component.

To define other material properties, the following parameters were assumed or taken from datasheets and experiments:

- Floor: Sports hall flooring with a reflection of $20 \%$.

- Wall: Interior wall with a reflection of $50 \%$.

- Ceiling: High reflectance ceiling with a reflection of $70 \%$.

- Window: Two-window insulating glass with a transmission of $70 \%$.

- Membrane: The layer structure of the real object was modelled in the software as one component. A diffuse reflection of $69 \%$ and a total diffuse transmission of $\tau_{v}$ Roof in Table 5 were assumed. Direct reflection and transmission were set to 0. See Table A3 in Appendix A for the material config file. 


\subsubsection{Daylight and Artificial Lighting}

The geometric model was built as a 3D model in SketchUp Pro 2018 and exported to Rhino 5. A screenshot of the 3D model can be found in Figure 4a. The simulations were performed in Diva 4.0.2.24, which is a plugin for Rhino to simulate daylighting and artificial lighting.

The material properties of the roof construction for the simulations were determined via experiments (see Section 2.2). An annual daylight simulation in Rhino 5 with Diva calculated the lighting parameters Daylight Availability (DA), Continuous Daylight Autonomy (CDA) and Useful Daylight Illuminance (UDI) as well as the electricity consumption of the artificial lighting. It ran in one-hour time step resolution.

The approach of the varied parameters for the different scenarios is shown in Table 5. Properties of the building envelope, the target indoor illuminance, the lighting control and the transmittance of the roof component were varied. The 18 investigated variants are shown with all varied parameters in Table 6. There were two main groups of similar scenarios with target illuminance values of 300 (Nos. 1-7) and $700 \mathrm{~lx}$ (Nos. 8-14). As a step in between, two 500 lx variants were also calculated (Nos. 17 and 18). In addition, two scenarios with increased and decreased transmittance were considered (Nos. 15 and 16). According to the German standard DIN V 18599-10:2016-10, a sports hall should have a minimum target illuminance of $300 \mathrm{~lx}$. In reality, artificial light is often used with higher target values so that scenarios with 500 and $700 \mathrm{~lx}$ are also tested. Overall, $700 \mathrm{~lx}$ is the realized situation in the case study building. Except scenario Nos. 15 and 16, the transmittance of the roof represents the clean surface case. No. 15 corresponds to the soiled surfaces and No. 16 to other materials with higher transmission. The user in lighting control mode "on/off" $(\mathrm{o} / \mathrm{o})$ switches the light statistically off when an indoor illuminance of $300 \mathrm{~lx}$ is exceeded. It is more than a time fixed schedule. This mimics a human operated situation. Dimming adapts the light power daylight sensitive to the target value. The target values also determine the installed lighting power (Table 5).

(a)

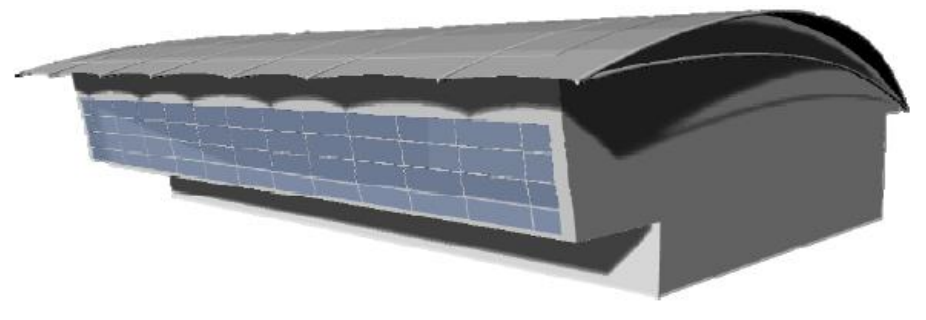

(b) light groups (LG) for the control

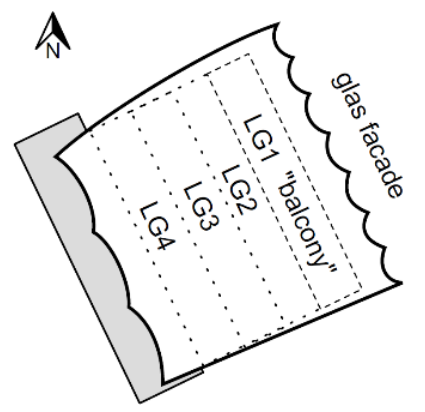

Figure 4. (a) 3D model in SketchUp, view from north; and (b) group definition of lighting sections.

Table 5. Overview of the values of the varied scenario parameters for Light Groups $2-4$. Not all of the possible combinations were simulated.

\begin{tabular}{|c|c|c|c|c|}
\hline Parameter: & Envelope & Target Illuminance [lx] & Control & $\tau_{v} \operatorname{Roof}[\%]$ \\
\hline & $\begin{array}{ll}\text { - } & \text { Opaque } \\
\text { - } & \text { Façade only } \\
\text { - } & \text { Roof only } \\
\text { - } & \text { Façade + roof }\end{array}$ & $\begin{array}{ll}\text { - } & 300\left(3.4 \mathrm{~kW}_{\mathrm{el}}\right) \\
\text { - } & 500\left(5.6 \mathrm{~kW}_{\mathrm{el}}\right) \\
\text { - } & 700\left(7.9 \mathrm{~kW}_{\mathrm{el}}\right)\end{array}$ & $\begin{array}{l}\text { - } \quad \text { Manual On/off } \\
\text { dimming }\end{array}$ & $\begin{array}{ll}- & 0.48 \\
\bullet & 0.74 \\
\bullet & 3\end{array}$ \\
\hline
\end{tabular}


Table 6. All used parameters of the 18 simulation scenarios in detail.

\begin{tabular}{|c|c|c|c|c|c|c|}
\hline No. & Name & $\tau_{v} \operatorname{Roof}[\%]$ & Target Illuminance [lx] & Control & Envelope & Comment \\
\hline 1 & Opaque 300 & 0.72 & 300 & $\mathrm{o} / \mathrm{o}=\operatorname{dim} .{ }^{1}$ & Opaque & Opaque building \\
\hline 2 & Reference 300 & 0.72 & 300 & On/off & Façade & Conventional building \\
\hline 3 & - & 0.72 & 300 & On/off & Roof & \\
\hline 5 & - & 0.72 & 300 & Dimming & Façade & - \\
\hline 6 & - & 0.72 & 300 & Dimming & Roof & - \\
\hline 7 & - & 0.72 & 300 & Dimming & Façade + roof & Real built geometry \\
\hline 9 & Reference 700 & 0.72 & 700 & On/off & Façade & Conventional building \\
\hline 10 & - & 0.72 & 700 & On/off & Roof & - \\
\hline 11 & - & 0.72 & 700 & On/off & Façade + Roof & Control mode comparison \\
\hline 12 & - & 0.72 & 700 & Dimming & Façade & - \\
\hline 13 & - & 0.72 & 700 & Dimming & Roof & - \\
\hline 14 & Real Building & 0.72 & 700 & Dimming & Façade + Roof & Real built situation, clean \\
\hline
\end{tabular}

${ }^{1}$ In an interior space without daylight, dimming and on/off control behave the same.

The lighting controls were defined in a grid of $1 \mathrm{~m} \times 1 \mathrm{~m}$ and illuminance was evaluated at $1 \mathrm{~m}$ height. The sports hall was divided into four light groups for the control, as shown in Figure $4 \mathrm{~b}$. The balcony at the glass façade was defined as Group 1 with an installed lighting power of $2538 \mathrm{~W}$ for the 700 lx target. The sections of the sports hall were defined as Groups $2-4$ with a lighting power of $2632 \mathrm{~W}$ each. In total, there is an installed lighting power of 10,434 W. For the simulation, a ballast lost factor of $28 \%$ and a standby-power of $8.4 \mathrm{~W}$ per LG meaning in total $25.2 \mathrm{~W}$ were assumed. The occupancy profile is 08:00-18:00 every day of the year (Figure A1). The weather file is located in the city Stuttgart in central Europe (Coordinates $48^{\circ} 47^{\prime} \mathrm{N} 9^{\circ} 11^{\prime} \mathrm{E}$ ) with an annual global horizontal irradiation of $1093 \mathrm{kWh} / \mathrm{m}^{2} / \mathrm{a}$.

\subsection{Daylight Metrics}

The Daylight Factor first proposed in the UK in the early 1900s is the ratio of internal illuminance to external horizontal illuminance under an overcast sky defined by the CIE luminance distribution [35].

In 1989, the Daylight Autonomy (DA) parameter was proposed by the "Association Suisse des Electriciens" and further developed by Reinhart from 2001 to 2004 [36]. It was the first dynamic approach for daylighting indoor evaluation. The $\mathrm{DA}_{\mathrm{xyz}}$ represents the percentage of hours during a period (i.e., year or the occupation times over one year) when the natural indoor illuminance value in an area overcomes a predefined threshold xyz indicated in the indices. It does not provide information about illuminance values below the defined threshold.

Rogers et al. (2006) [37] developed a modification of the DA called the continuous Daylight Autonomy $\left(\mathrm{cDA}_{\mathrm{xyz}}\right)$. With respect to the DA definition, it additionally counts partial values below the specified illumination level threshold xyz. A timely situation with CDA of $50 \%$ is not unique. It could mean that half of the time the illuminance threshold was completely reached and the other half of the time it was completely dark. It could also mean that all the time the threshold was only half reached.

The Useful Daylight Illuminances (UDI), proposed by Mardaljevic and Nabil in 2005, is also a dynamic daylight performance measure that is based on work plane illuminances [36]. It also represents the percentage of hours during a period when the natural indoor illuminance values lie in certain borders, namely $<100 \mathrm{~lx}$, within 100-2000 and above $2000 \mathrm{~lx}\left(\mathrm{UDI}_{<100}, \mathrm{UDI}_{100-2000}\right.$ and $\left.\mathrm{UDI}_{>2000}\right)$. As its name suggests, it aims to determine when daylight levels are "useful" for the occupant, that is, neither too dark ( $<100$ lx) nor too bright (>2000 lx) [36]. The upper threshold is meant to detect times when an oversupply of daylight might lead to visual and/or thermal discomfort [36]. The $\mathrm{UDI}_{>2000}$ is equivalent to a $\mathrm{DA}_{2000}$. 


\section{Results}

The results of the simulations are presented using daylight indicators and energy demand analysis. The results hold for the case study building geometry investigated in this study which has a speciality with an indoor "balcony" at the side of the glass façade (Light Group 1). The presented results concerning energy are related to Light Groups 2-4 located at the sport field. They are shaded from the "balcony" and further away from the glass façade than fields in other buildings directly adjacent to a transparent façade.

\subsection{Daylight}

Daylight indicators in the current study are the daylight autonomy (DA), the continuous daylight autonomy (CDA) and the useful daylight illuminance (UDI) with certain thresholds. The results of their spatial distribution are shown in Figure 5a-c. Light Group 1 (LG1, Figure 4b) adjacent to the window on the so-called "indoor balcony" was also included here. LG 1 was excluded for the energy demand analyses of lightening the field in the following section. Only the sport field was placed in focus to be more comparable to other sport buildings. The DA was calculated with a hard threshold and therefore applicable for switch on/off situations. The CDA was applied for dimming systems, as it weights the differences to the threshold.

The $\mathrm{DA}_{\mathrm{xxx}}$ with the respective thresholds 300, 500 and 700 lx increases of course with more light transmitting components. The single translucent roof shows a higher daylight usage $\left(\mathrm{DA}_{300} 17 \%\right.$, $\mathrm{CDA}_{300} 48 \%$ ) compared to the single transparent façade (DA $3002 \%, \mathrm{CDA}_{300} 34 \%$ ), see Table 7 . The spatial distribution in the façade-only cases is highly asymmetrical towards the transparent façade (Figure 5a). Especially, the shaded edge under the "balcony" exhibits very dark areas. The Façade + roof cases deliver a more homogeneous daylight supply over the field especially concerning the CDA. The corner below the balcony remains the darkest area. Very homogeneous illuminance distributions achieve the roof-only envelope scenarios. However, the $\mathrm{DA}_{700}$ and $\mathrm{CDA}_{700}$ of $0 \%$ and $23 \%$ are smaller than the "facade + roof" cases with $1.5 \%$ and $38 \%$ (Figure $5 \mathrm{~b}$ ).

Increasing/decreasing the roof transmittance from $0.72 \%$ to $3 \% / 0.47 \%$ changes the CDA in the $7001 x$ cases from the mentioned $38 \%$ to $70 \% / 30 \%$ (Figure $5 \mathrm{c}$ and Table 7 ). The DA considerably changes from $1.5 \%$ to $47 \% / 0 \%$. The large transmittance of $3 \%$ (scenario No. 16) gives tremendous benefit for the daylight performance as also seen later in the electricity demand.

The balcony area has the highest daylight performance in the cases with glass façade as it is adjacent to the window. The UDI > 2000 indicates the risk of glare. This is harmless for all scenarios except No. 16. A shading system for the façade would be recommendable in that case. Even in the centre regions of the field, some signs of glare risk can be seen in Figure 5c. Going to such large transmittance values in a roof would require a closer investigation of glare and shading measures.

Table 7. Summary of annual daylight indicators for all scenarios.

\begin{tabular}{|c|c|c|c|}
\hline & \multicolumn{3}{|c|}{$\mathrm{DA}_{\mathbf{x x x}} / \mathrm{CDA}_{\mathbf{x x x}}[\%]$} \\
\hline & $3001 x$ & $5001 x$ & $700 \mathrm{~lx}$ \\
\hline Opaque, $\tau_{\mathrm{v}} 0.72 \%$ & $0.00 / 0.00$ & & $0.00 / 0.00$ \\
\hline Façade-only & $2.12 / 33.93$ & $0.07 / 20.57$ & $0.00 / 14.71$ \\
\hline Roof-only & $16.74 / 48.12$ & & $0.00 / 23.04$ \\
\hline Facade + Roof & $39.49 / 66.56$ & $13.60 / 50.12$ & $1.47 / 37.63$ \\
\hline Facade + Roof, $\tau_{v} 0.47 \%$ & & & $0.02 / 29.93$ \\
\hline Facade + Roof, $\tau_{v} 3 \%$ & & & $46.86 / 70.19$ \\
\hline
\end{tabular}




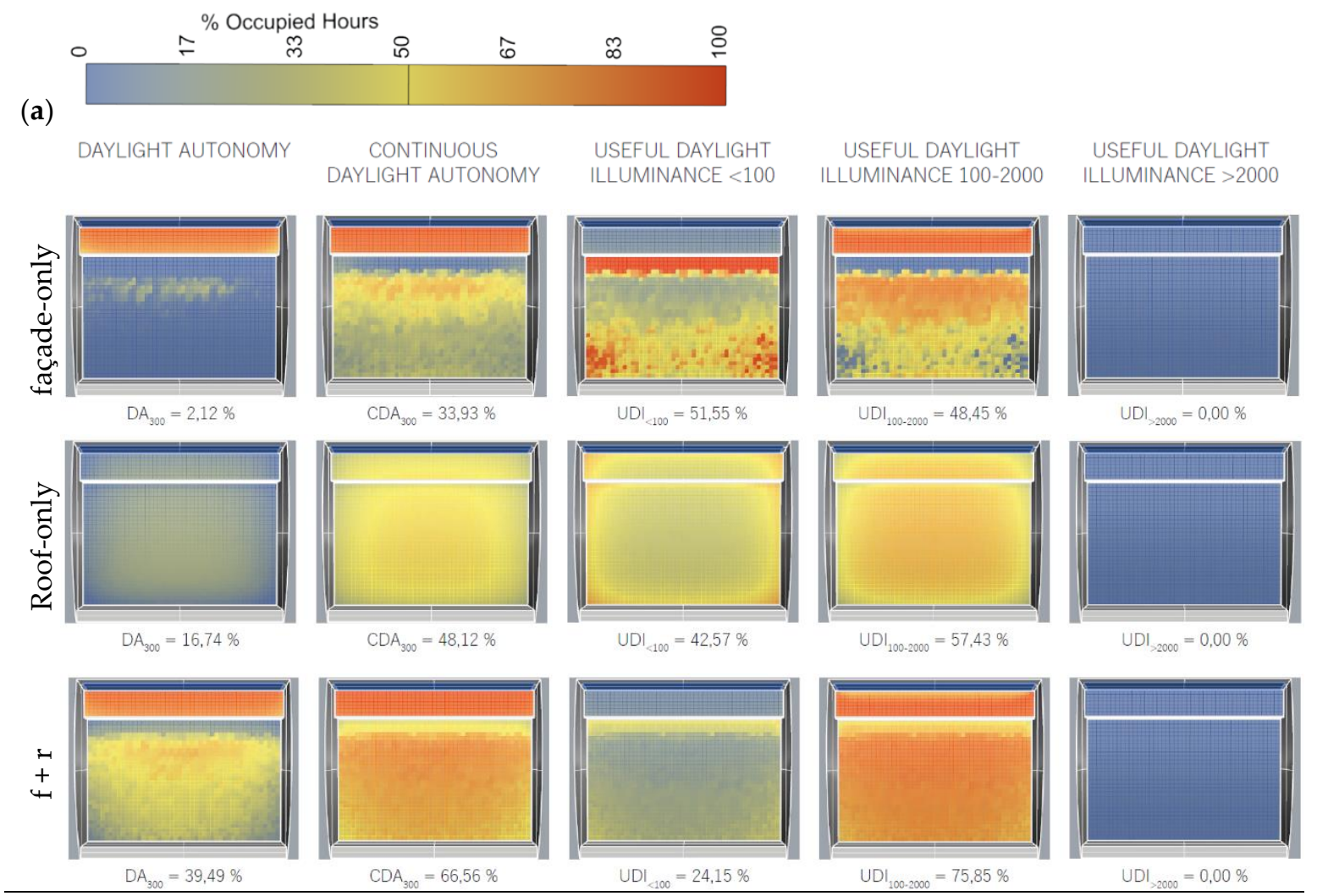

(b)
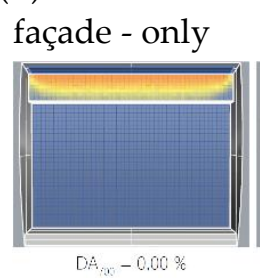

(c)

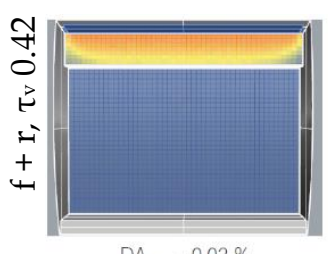

$\mathrm{DA}_{700}=0,02 \%$

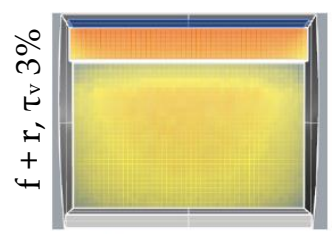

$D A_{700}=46,86 \%$ roof - only

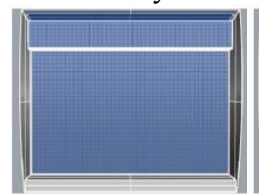

$D A_{700}=0.00 \%$

$\left.\Delta\right|_{100}=24,15 \%$

$\mathrm{UDI}_{100 \cdot 2000}=75,85 \%$

$U D I_{>2000}=0,00 \%$

façade + roof

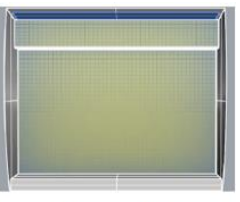

$\mathrm{CDA}_{2 \mathrm{PO}}=23.04 \%$

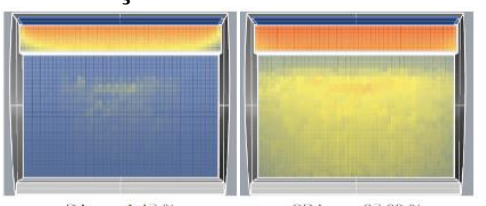

$\mathrm{CDA}_{7 \mathrm{co}}-37,63 \%$

$\mathrm{DA}_{700}=1,47 \%$ $\begin{array}{lcc}\text { USEFUL DAYLIGHT } & \text { USEFUL DAYLIGHT } & \text { USEFUL DAYLIGHT } \\ \text { ILLUMINANCE }<100 & \text { ILLUMINANCE 100-2000 } & \text { ILLUMINANCE }>2000\end{array}$ DAYLIGHT AUTONOMY

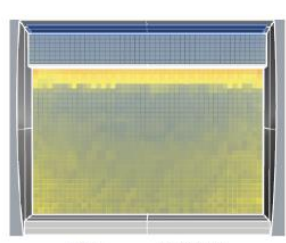

UDI $_{100}=28,90 \%$

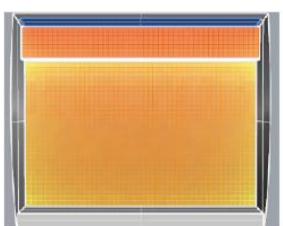

$\mathrm{CDA}_{700}=70,19 \%$

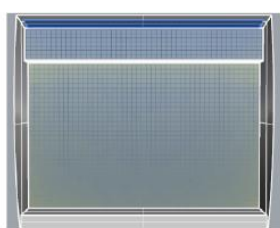

$\mathrm{UDI}_{\mathcal{1} 100}=11,56 \%$

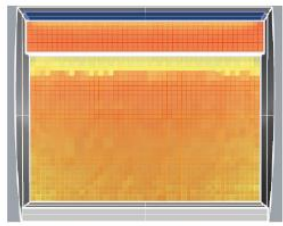

$\mathrm{UDI}_{100-2000}=71,10 \%$

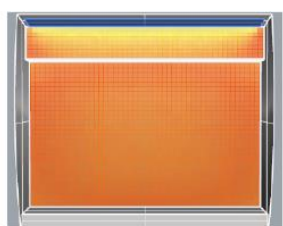

$\mathrm{UDI}_{100-2000}=83,63 \%$

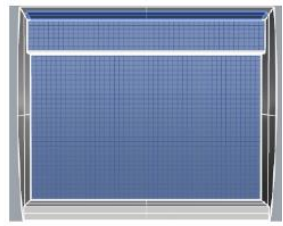

$\mathrm{UDI}_{-2000}=0,00 \%$

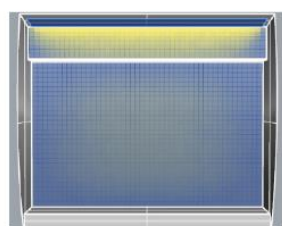

$\mathrm{UDI}_{2000}=4,81 \%$

Figure 5. Spatial distribution of annual daylight indicators for scenarios with target illuminance: (a) 300 lx, Nos. 1-7; (b) 700 lx, Nos. 8-14; and (c) varied transmittance $\tau_{v}$, Nos. 15 and 16. Scenarios Nos. 17 and 18 can be found in Figure A2. 


\subsection{Electricity Consumption}

For the energy consumption of any automated system, the control behaviour is crucial. To interpret and transfer the results in this work to other situations, an understanding of the two used control modes is essential. As an example, for the operation of the control modes, two visualisations of the transient behaviour are shown in Figure 6. The users in "o/o" mode switch off the lighting with a certain probability if illuminance values above $300 \mathrm{~lx}$ occur. The dimming always dims the lighting following a photo sensor and the target illuminance value. Hence, the dimming mode in Figure $6 \mathrm{~b}$ shows many times with partly operated light in grey colour.

(a)

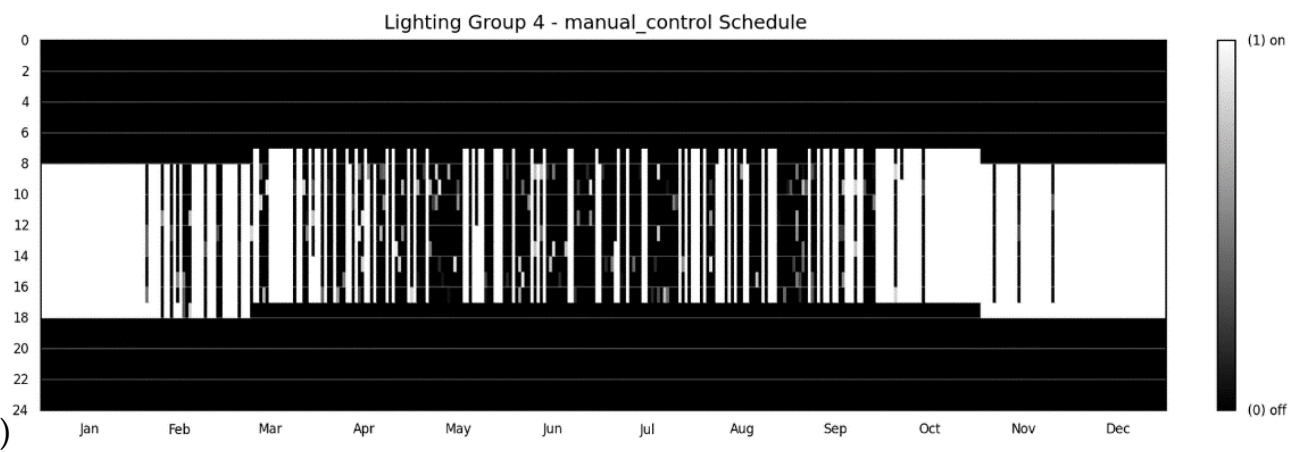

(b)

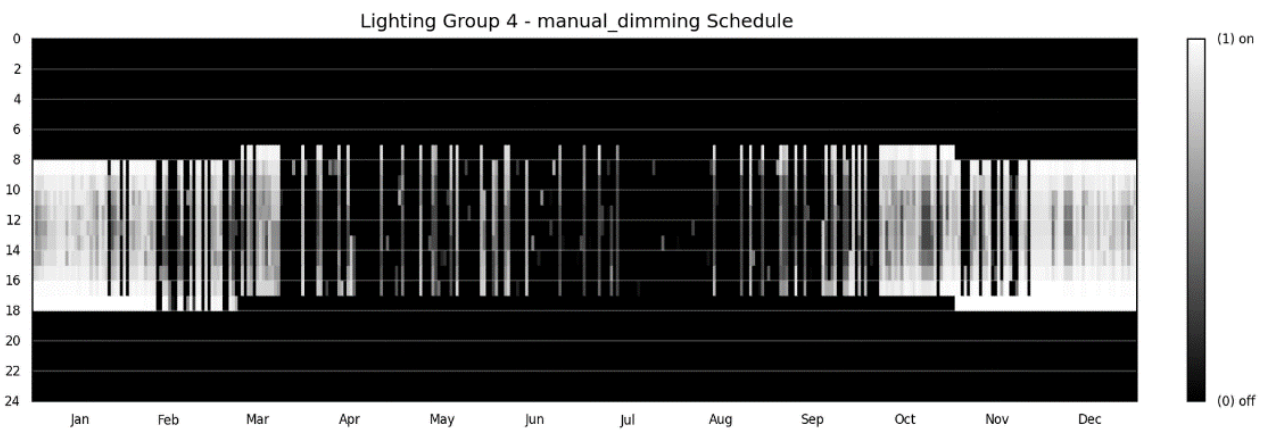

Figure 6. Operation of the control modes as an example: (a) on/off (o/o) in No. 4; and (b) dimming in No. 16

The results of the absolute electricity demand for artificial lighting $\left(\mathrm{Q}_{\mathrm{el}, \mathrm{al}}\right)$ in all scenarios are presented in Figure 7. All absolute values of $\mathrm{Q}_{\mathrm{el}, \mathrm{al}}$ including the LG1 at the balcony can be found in Table A2. The relative savings are shown in Table 8 and in absolute values in Table A4. The table contains much information. The column scenario No. is related to the scenario No. in the rows. The Unit is per cent. Negative values are savings. For the detailed scenario No. parameter settings, see Table 6 . The header here in Table 8 indicates a short description of the scenario settings. Relations of a scenario with itself are highlighted with grey. Blue cells are referred to in the text. As an example for the reading of the table, the blue cell in the very bottom of the column with the scenario No. 14 means that variant No. 14 saves 10\% electrical energy for AL compared to the case No. 11 indicated at the very left of the row. Going in that row to the left until column with No. 4 means that No. 4 compared to No. 11 saves $57 \%$.

First, the absolute energy demand in the same geometry (i.e., "façade") increases with increasing the target illuminance values from 300 over 500 to 700 lx. Comparing the different control modes "dimming" and "on/off", "dimming" reduces the demand in all daylight variants. In the scenarios "Façade + roof" which equal the case study building's geometry, this sums up to $-24 /-10 \%$ for a target illuminance of $300 \mathrm{~lx} / 700 \mathrm{~lx}$ (Table 8 line “No. 4/11" blue cells). Higher target illuminances in this setting lead to less relative savings. This is because of the higher demand combined with only little higher natural daylight using potential. The absolute savings increase slightly from 1.9 to $2.0 \mathrm{MWh} / \mathrm{a}$. 
It becomes obvious in Figure 7 that the highest daylight impact on lowering the $Q_{\mathrm{el}, \mathrm{al}}$ over all different target illuminances can be generated by using a translucent membrane roof in combination with a transparent façade. In the cases of $3001 x / 7001 x$, the membrane added to the transparent façade cases reduces the $\mathrm{Q}_{\mathrm{el}, \mathrm{al}}$ drastically by $42 \% / 32 \%$ when relating the dimming control cases to the conventional building reference cases "façade-only" with on/off control (Table 8 line "No. 2/9" blue cells). This comparison holds for a modern new building compared to a conventional one. The influence of only the translucent roof reveals when comparing No. 7 to No. 5 (300 lx) and No. 14 to No. 12 (700 lx). Then, 38\% (3.8 MWh/a) and 30\% (7.2 MWh/a) can be saved, respectively. The 30\% savings are the main result of the article and highlighted with the blue cell and white text in Table 8 .

The influence of lowering (soiling) and increasing the transmittance of the roof is investigated with Nos. 15 and 16 compared to No. 14. The soiling of the OM after two years (No. 15) which reduces the light transmittance $\tau_{\mathrm{v}}$ from $0.72 \%$ to $0.47 \%$ increases the $Q_{\text {el,al }}$ by $12 \%$. A roof with $\tau_{\mathrm{v}}=3 \%$ lowers it by $41 \%$ (Table 8 , line "No. 14", blue cells). By chance, the $Q_{\mathrm{el}, \text { al }}$ in case No. 15 with low $\tau_{\mathrm{v}}$ ("700 dim 0.47 " in Figure 7) almost equals No. 11 with o/o control and clean $\tau_{v}$ of $0.72 \%$ ("700 dim" Façade + roof in Figure 7).

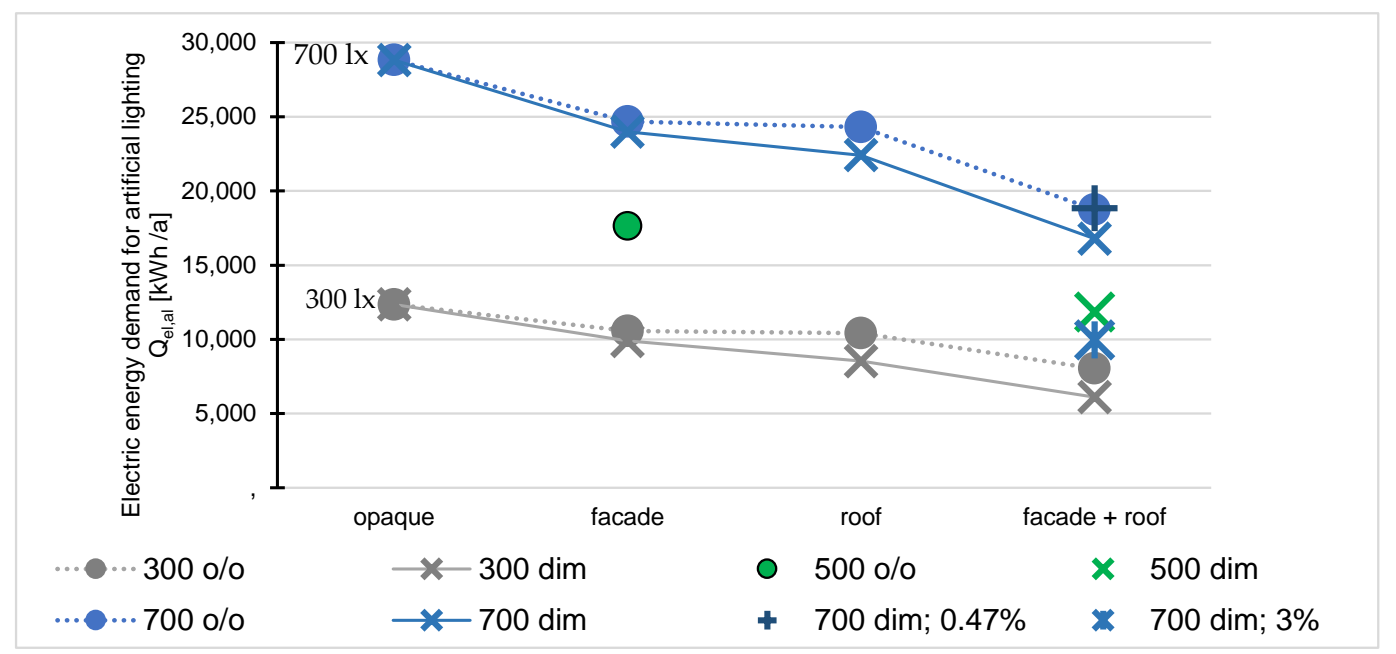

Figure 7. Electrical energy demand for artificial lighting.

Table 8. Relative electrical energy savings for AL: The column scenario No. is related to the scenario No. in the rows. The Unit is per cent. Negative values are savings. For detailed scenario No. parameter settings, see Table 6 . The header here indicates a short description of the scenario settings. For example, the blue cell in the very bottom of the column with the scenario No. 14 means that variant No. 14 saves $10 \%$ electrical energy for AL compared to the case No. 11 indicated at the very left of the row. For another example, going in that row from the blue cell to the left until column with No. 4 on the top means that No. 4 compared to No. 11 saves $57 \%$. Grey cells are relations of a scenario with itself and hence contain a 0 representing no savings.

\begin{tabular}{|c|c|c|c|c|c|c|c|c|c|c|c|c|c|c|c|c|c|c|}
\hline \multirow[t]{3}{*}{ [\%] } & \multicolumn{7}{|c|}{$3001 x$} & \multicolumn{7}{|c|}{$7001 x$} & \multicolumn{2}{|c|}{$\tau$ Low $\mid$ High } & \multicolumn{2}{|c|}{$5001 x$} \\
\hline & & & $\mathrm{O} / \mathrm{O}$ & & & Dim & & & & $\mathrm{O} / \mathrm{O}$ & & & Dim & & Dim & & $\mathrm{O} / \mathrm{O}$ & Dim \\
\hline & op. & f. & r. & $f+r$ & f. & r. & $\mathbf{f}+\mathbf{r}$ & op. & f. & r. & $f+r$ & f. & r. & $\mathbf{f}+\mathbf{r}$ & $\mathbf{f}+\mathbf{r}$ & $f+r$ & f. & $\mathbf{f}+\mathbf{r}$ \\
\hline No. & 1 & 2 & 3 & 4 & 5 & 6 & 7 & 8 & 9 & 10 & 11 & 12 & 13 & 14 & 15 & 16 & 17 & 18 \\
\hline 1 & 0 & -14 & -16 & -35 & -20 & -31 & -51 & 133 & 100 & 97 & 52 & 94 & 81 & 36 & 52 & -19 & 43 & -4 \\
\hline 8 & -57 & -63 & -64 & -72 & -66 & -70 & -79 & 0 & -14 & -16 & -35 & -17 & -22 & -42 & -35 & -65 & -39 & -59 \\
\hline 2 & 17 & 0 & -2 & -24 & -6 & -19 & -42 & 172 & 133 & 130 & 77 & 127 & 112 & 59 & 78 & -6 & 67 & 12 \\
\hline 9 & -50 & -57 & -58 & -67 & -60 & -65 & -75 & 17 & 0 & -2 & -24 & -3 & -9 & -32 & -24 & -60 & -29 & -52 \\
\hline 5 & 25 & 7 & 5 & -19 & 0 & -14 & -38 & 191 & 150 & 146 & 89 & 143 & 127 & 70 & 90 & 1 & 78 & 20 \\
\hline 12 & -49 & -56 & -57 & -67 & -59 & -64 & -75 & 20 & 3 & 1 & -22 & 0 & -7 & -30 & -22 & -59 & -27 & -51 \\
\hline 14 & -26 & -37 & -38 & -52 & -41 & -49 & -64 & 72 & 47 & 45 & 12 & 43 & 34 & 0 & 12 & -41 & 5 & -30 \\
\hline 17 & -30 & -40 & -41 & -54 & -44 & -52 & -65 & 63 & 40 & 38 & 6 & 36 & 27 & -5 & 7 & -44 & 0 & -33 \\
\hline 4 & 54 & 32 & 30 & 0 & 23 & 6 & -24 & 259 & 207 & 203 & 133 & 199 & 179 & 109 & 134 & 24 & 119 & 47 \\
\hline 11 & -34 & -44 & -44 & -57 & -47 & -54 & -67 & 54 & 32 & 30 & 0 & 28 & 20 & -10 & 0 & -47 & -6 & -37 \\
\hline
\end{tabular}


The area of the sport field supplied by Light Groups 2-4 adds up to $1215 \mathrm{~m}^{2}$. This results in an annual area specific demand of $13.8 \mathrm{kWh}$ el $/ \mathrm{m}^{2} / \mathrm{a}$ for scenario No. 14 (the realised membrane case study building) compared to the reference conventional building case No. 9 with $20.3 \mathrm{kWh}_{\mathrm{el}} / \mathrm{m}^{2} / \mathrm{a}$ (only transparent façade, manual on/off control). That envelope case with the dimming control (No. 12) demands $19.7 \mathrm{kWh}$ el $/ \mathrm{m}^{2} / \mathrm{a}$. The realized envelope situation with o/o control (No. 11) causes $15.4 \mathrm{kWh}_{\mathrm{el}} / \mathrm{m}^{2} / \mathrm{a}$.

\section{Discussion and Conclusions}

A limitation of the current work is the occupancy profile used. It was assumed as 08:00-18:00, 365 days a year. The transfer of the saving potential in relative numbers on other buildings with more night-time use may be critical. The absolute numbers scaled with the illuminated field area and occupancy days over the whole year could be more accurate.

The so-called "indoor balcony" decreases the daylight usage of the analysed sport field in the current situation. Other fields adjacent to a glass façade would perform more promising. In that sense, the geometrical situation of the current study is conservative for the daylight performance. As opposed to this, the assumed occupancy schedule (08:00-18:00) lies strongly inside the daylight times. Hence, this boundary condition is favourable for the daylight performance.

Keep in mind that the (absolute or area specific) energy values indicated in the text always refer only to the sport field and not to the total building area or the indoor balcony.

Transferable findings are:

- Combining a translucent roof with a transparent north façade performs best for lighting the field with a low electricity demand for artificial lighting of $13.8 \mathrm{kWh}$ el $/ \mathrm{m}^{2} / \mathrm{a}$ under $700 \mathrm{~lx}$ target illuminance. Comparing this value to reported total building electricity consumptions of 32 [8], 50 [9] and $105 \mathrm{kWh}_{\mathrm{el}} / \mathrm{m}^{2} / \mathrm{a}$ [10] for dry sports centres, it appears to be very low, especially for the field area where the highest lighting load occurs.

- Adding this membrane roof even with the relatively low $\tau_{\mathrm{v}}$ of $0.72 \%$ to a glass façade decreases the artificial lighting by $30 \%$.

- A high roof transmittance $\tau_{\mathrm{v}}$ of $3 \%$ delivers great daylight autonomy of $47 \%$ and a CDA of $70 \%$ resulting in only $8.2 \mathrm{kWh}$ el $/ \mathrm{m}^{2} /$ a electricity demand for artificial lighting. However, the risk of glare starts to become an issue around that value of $\tau_{\mathrm{v}}$, especially close to the glass façade.

- Soiling decreases the hybrid construction's daylight performance (façade + roof), but not as much as expected. Lowering the $\tau_{\mathrm{v}}$ from $0.72 \%$ to $0.46 \%$ increases the electricity demand from 13.8 to only $15.5 \mathrm{kWh}$ el $/ \mathrm{m}^{2} / \mathrm{a}$, probably because of the support from the glass façade. In a situation with roof-only daylight, this could be worse. This scenario was not included yet and could be a focus of another study.

- To completely exploit daylight potentials, dimming control is recommended. It decreases electricity consumption by $10 \% / 24 \%$ for target illuminances of $7001 \mathrm{l} / 3001 \mathrm{x}$ compared to a manual user "on/off" behaviour. This percentage is lower than results from other articles because of the reference in this study, which is not a simple time schedule. In fact, the o/o control imitates human user behaviour with switching off the light very often.

Even though the electricity savings and the illuminance distribution of a roof-only translucent envelope may be better than the hybrid combination façade + roof, a transparent glass façade has a positive effect on the visual comfort feeling of the persons inside. Hence, a combination system could lead to an optimum configuration. A future study could use a more general setting with an occupancy profile with more night time use and a more common geometry without an indoor balcony.

Author Contributions: Conceptualization, D.G. and A.B.; Data curation, D.G. and A.B.; Formal analysis, D.G. and A.R.; Funding acquisition, A.B. and U.E.; Investigation, D.G., A.R. and A.B.; Methodology, D.G. and A.B.; Project administration, A.B. and D.G.; Software, A.R.; Visualization, D.G.; Writing-original draft, D.G.; Writing-review \& editing, D.G., A.R., A.B. and U.E. 
Funding: The current work is embedded in the research project "Doppelte Membrankonstruktion mit low-e Beschichtung für ein transluzentes Dach über dem Neubau eines Sportzentrums in Fürth" with acronym SoFt funded by the German Federal Ministry for Economic Affairs and Energy. Code: 03ET1163A. Project partners: ZAE Bayern, FAB Architekten, Wacker Ingenieure, F.I.B.U.S. Funds for covering the costs to publish in open access are provided by the Research Centre for Sustainable Energy Technologies zafh.net via the innovation and transfer project "M4_LAB-HFT Innovationslabor für die Metropolregion 4.0" of the German Federal Ministry of Education and Research (BMBF).

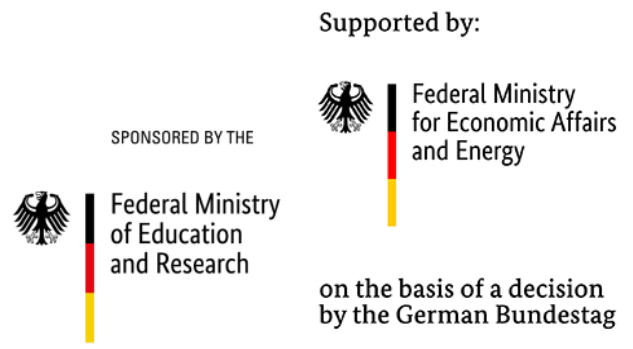

Acknowledgments: Thanks to Mister Swen Brodkorb from the architectural office fab_architekten (http:/ / www. fab-architekten.de/) for the supply with construction plans and to David Offtermatt and Hannes Marx for fruitful discussions about DIVA. The support provided by Volker Fux was greatly appreciated same as the assistance by all the caretakers of the building especially Sascha Meyer and Klaus Bieberich.

Conflicts of Interest: The authors declare no conflict of interest. The founding sponsors had no role in the design of the study; in the collection, analyses, or interpretation of data; in the writing of the manuscript, and in the decision to publish the results.

\section{Nomenclature}

\section{Abbreviations}

al

el.

tfa

tot

$\mathrm{v}$

PE

PES

PTFE

PVC

IM

MI

$\mathrm{OM}$

IV

DA

CDA

UDI

CCT

Symbols

Q

Qel,tot

$\mathrm{Q}_{\mathrm{el}, \mathrm{al}}$

$\tau_{\mathrm{V}}$

$\mathrm{E}_{\mathrm{V}}$

$\mathrm{G}_{\text {glob }}$
Artificial lighting

electrical

Total floor area

Total

visual

Primary Energy

Polyester

Polytetrafluoroethylene

Polyvinyl chloride

Inner Membrane

Membrane Interspace

Outer Membrane

Interior Volume

Daylight Availability

Continuous Daylight Autonomy

Useful Daylight Illuminance

correlated color temperature

Energy

Total electricitydemand

[kWh]

[kWh]

[kWh]

$\begin{array}{ll}\text { El. demand for artificial lighting } & {[\mathrm{kW}} \\ \text { Light transmittance } & {[\%]}\end{array}$

(visual) illuminance [lx]

Global irradiance $\quad\left[\mathrm{W} / \mathrm{m}^{2}\right]$ $[\mathrm{l}]$

\section{Comment}

With construction 


\section{Appendix A}

Table A1. Building parameters and indicators for the calculated energy demand following the German Energy Saving Ordinance "EnEV 2009, Energieeinsparverordnung".

\begin{tabular}{cc}
\hline Heated Area & $\mathbf{A}_{\text {net ground area }}=\mathbf{4 2 2 1} \mathbf{~ m}^{\mathbf{2}}$ \\
\hline Annual final energy demand & $178 \mathrm{kWh} / \mathrm{m}^{2} \mathrm{a}$ \\
Annual PE demand ${ }^{1}$ & $\mathrm{Q}_{\mathrm{P}}=129 \mathrm{kWh} / \mathrm{m}^{2} \mathrm{a}$ \\
Average opaque envelope U-value & $0.23 \mathrm{~W} / \mathrm{m}^{2} \mathrm{~K}$ \\
Average transparent envelope U-value & $1.60 \mathrm{~W} / \mathrm{m}^{2} \mathrm{~K}$ \\
\hline
\end{tabular}

${ }^{1}$ heating with wood.

Table A2. Absolute electricity demand for AL and daylight indicators of all scenarios.

\begin{tabular}{|c|c|c|c|c|c|}
\hline \multirow{2}{*}{ Scenario Name } & \multicolumn{5}{|c|}{ Energy Consumption [kWh] } \\
\hline & LG1 & LG2 & LG3 & LG4 & LG2-LG4 \\
\hline 01_t0.72_300lx_opaque & 3971 & 4117 & 4117 & 4117 & 12,351 \\
\hline 02_t0.72_3001x_facade_onoff & 1362 & 4026 & 3194 & 3359 & 10,578 \\
\hline 03_t0.72_300lx_roof_onoff & 3271 & 3457 & 3266 & 3695 & 10,418 \\
\hline 04_t0.72_300lx_facade + roof_onoff & 1339 & 3039 & 2404 & 2590 & 8033 \\
\hline 05_t0.72_300lx_facade_dim & 803 & 4017 & 2827 & 3047 & 9891 \\
\hline 06_t0.72_300lx_roof_dim & 2748 & 2881 & 2542 & 3109 & 8532 \\
\hline 07_t0.72_300lx_facade + roof_dim & 762 & 2441 & 1719 & 1949 & 6109 \\
\hline 08_t0.72_700lx_opaque & 9264 & 9607 & 9607 & 9607 & 28,820 \\
\hline 09_t0.72_700lx_facade_onoff & 3176 & 9394 & 7452 & 7836 & 24,682 \\
\hline 10_t0.72_7001x_roof_onoff & 7630 & 8067 & 7621 & 8620 & 24,309 \\
\hline 11_t0.72_700lx_facade + roof_onoff & 3124 & 7092 & 5610 & 6042 & 18,744 \\
\hline 12_t0.72_700lx_facade_dim & 2533 & 9385 & 7085 & 7525 & 23,996 \\
\hline 13_t0.72_7001x_roof_dim & 7107 & 7491 & 6887 & 8035 & 22,413 \\
\hline 14_t0.72_700lx_facade + roof_dim & 2404 & 6494 & 4898 & 5396 & 16,788 \\
\hline 15_t0.47_700lx_facade + roof_dim & 2541 & 7214 & 5236 & 6379 & 18,829 \\
\hline 16_t3.00_700lx_facade + roof_dim & 1619 & 3647 & 2620 & 3687 & 9954 \\
\hline \multirow{4}{*}{$\begin{array}{l}\text { 17_t0.72_500lx_facade_onoff } \\
\text { 18_t0.72_500lx_facade + roof_dim }\end{array}$} & 2269 & 6710 & 5323 & 5597 & 17,630 \\
\hline & 1536 & 4467 & 3504 & 3860 & 11,831 \\
\hline & \multicolumn{5}{|c|}{ DA/CDA } \\
\hline & \multicolumn{2}{|c|}{$3001 x$} & $5001 x$ & & $7001 x$ \\
\hline 01_t0.72_300lx_opaque & \multicolumn{2}{|c|}{$0.00 \% / 0.00 \%$} & & & \\
\hline 02_t0.72_3001x_facade_onoff & \multicolumn{2}{|c|}{$2.12 \% / 33.93 \%$} & & & \\
\hline 03_t0.72_300lx_roof_onoff & \multicolumn{2}{|c|}{$16.74 \% / 48.12 \%$} & & & \\
\hline 04_t 0.72 _300lx_facade + roof_onoff & \multicolumn{2}{|c|}{$39.49 \% / 66.56 \%$} & & & \\
\hline 05_t0.72_300lx_facade_dim & \multirow{2}{*}{\multicolumn{2}{|c|}{$\begin{array}{l}2.12 \% / 33.93 \% \\
16.74 \% / 48.12 \%\end{array}$}} & & & \\
\hline 06_t0.72_3001x_roof_dim & & & & & \\
\hline 07_t0.72_300lx_facade + roof_dim & \multicolumn{2}{|c|}{$\begin{array}{l}10.74 \% / 48.12 \% \\
39.49 \% / 66.56 \%\end{array}$} & & & \\
\hline 08_t0.72_700lx_opaque & \multicolumn{5}{|c|}{$0.00 \% / 0.00 \%$} \\
\hline 09_t0.72_700lx_facade_onoff & \multicolumn{5}{|c|}{$0.00 \% / 14.71 \%$} \\
\hline 10_t0.72_700lx_roof_onoff & \multicolumn{5}{|c|}{$0.00 \% / 23.04 \%$} \\
\hline 11_t 0.72 _700lx_facade + roof_onoff & \multicolumn{5}{|c|}{$1.47 \% / 37.63 \%$} \\
\hline 12_t0.72_700lx_facade_dim & \multicolumn{5}{|c|}{$0.00 \% / 14.71 \%$} \\
\hline 13_t0.72_7001x_roof_dim & \multicolumn{5}{|c|}{$0.00 \% / 23.04 \%$} \\
\hline 14_t0.72_700lx_facade + roof_dim & \multicolumn{5}{|c|}{$1.47 \% / 37.63 \%$} \\
\hline 15_t0.47_700lx_facade + roof_dim & \multicolumn{5}{|c|}{$0.02 \% / 29.93 \%$} \\
\hline 16_t3.00_700lx_facade + roof_dim & \multicolumn{5}{|c|}{$46.86 \% / 70.19 \%$} \\
\hline 17_t0.72_500lx_facade_onoff & \multicolumn{5}{|c|}{$0.07 \% / 20.57 \%$} \\
\hline 18_t0.72_500lx_facade + roof_dim & \multicolumn{5}{|c|}{$13.60 \% / 50.12 \%$} \\
\hline
\end{tabular}


Table A3. Material configuration file of DIVA.

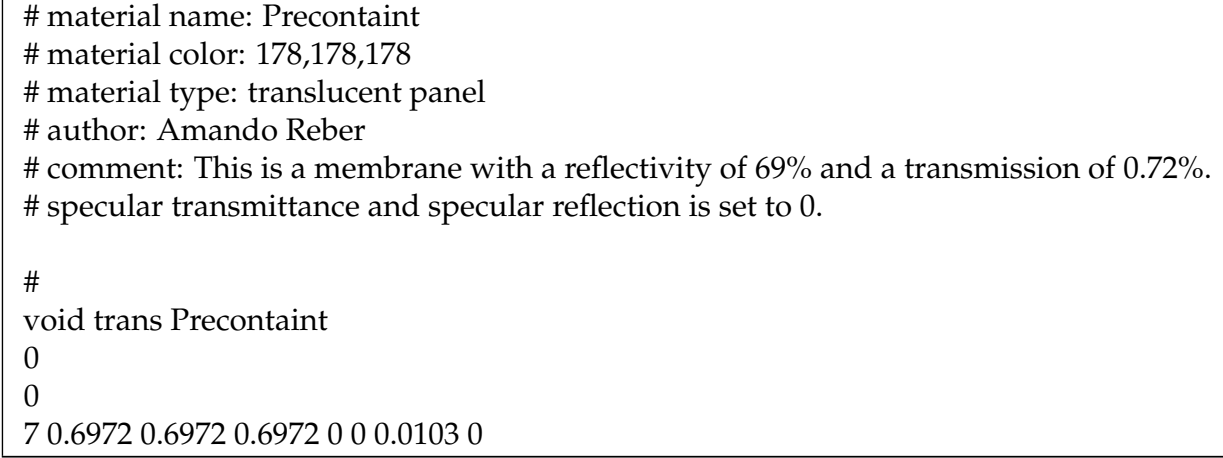

Table A4. Absolute electrical energy savings for AL in completive to Table 8: Absolute differences of the column scenario related to the row scenario No. [MWh/a] (negative values are savings).

\begin{tabular}{|c|c|c|c|c|c|c|c|c|c|c|c|c|c|c|c|c|c|c|}
\hline \multirow[b]{4}{*}{ No. } & \multicolumn{7}{|c|}{$300 \mathrm{~lx}$} & \multicolumn{7}{|c|}{$700 \mathrm{~lx}$} & $\tau$ Low & High & \multicolumn{2}{|c|}{$500 \mathrm{~lx}$} \\
\hline & & & $\mathrm{O} / \mathrm{O}$ & & & Dim & & & & $\mathrm{O} / \mathrm{O}$ & & & Dim & & Dim & & $\mathrm{O} / \mathrm{O}$ & Dim \\
\hline & op. & f. & r. & $f+r$ & f. & r. & $\mathbf{f}+\mathbf{r}$ & op. & f. & $\mathrm{r}$. & $f+r$ & f. & r. & $\mathbf{f}+\mathbf{r}$ & $f+r$ & $f+r$ & f. & $f+r$ \\
\hline & 1 & 2 & 3 & 4 & 5 & 6 & 7 & 8 & 9 & 10 & 11 & 12 & 13 & 14 & 15 & 16 & 17 & 18 \\
\hline 1 & 0.0 & -1.8 & -1.9 & -4.3 & -2.5 & -3.8 & -6.2 & 16.5 & 12.3 & 12.0 & 6.4 & 11.6 & 10.1 & 4.4 & 6.5 & -2.4 & 5.3 & -0.5 \\
\hline 8 & -16.5 & -18.2 & -18.4 & -20.8 & -18.9 & $9-20.3$ & -22.7 & 0.0 & -4.1 & -4.5 & -10.1 & -4.8 & -6.4 & -12.0 & -10.0 & -18.9 & -11.2 & -17.0 \\
\hline 2 & 1.8 & 0.0 & -0.2 & -2.5 & -0.7 & -2.0 & -4.5 & 18.2 & 14.1 & 13.7 & 8.2 & 13.4 & 11.8 & 6.2 & 8.3 & -0.6 & 7.1 & 1.3 \\
\hline 9 & -12.3 & -14.1 & -14.3 & -16.6 & -14.8 & $3-16.1$ & -18.6 & 4.1 & 0.0 & -0.4 & -5.9 & -0.7 & -2.3 & -7.9 & -5.9 & -14.7 & -7.1 & -12.9 \\
\hline 5 & 2.5 & 0.7 & 0.5 & -1.9 & 0.0 & -1.4 & -3.8 & 18.9 & 14.8 & 14.4 & 8.9 & 14.1 & 12.5 & 6.9 & 8.9 & 0.1 & 7.7 & 1.9 \\
\hline 12 & -11.6 & -13.4 & -13.6 & -16.0 & -14.1 & $1-15.5$ & -17.9 & 4.8 & 0.7 & 0.3 & -5.3 & 0.0 & -1.6 & -7.2 & -5.2 & -14.0 & -6.4 & -12.2 \\
\hline 14 & -4.4 & -6.2 & -6.4 & -8.8 & -6.9 & -8.3 & -10.7 & 12.0 & 7.9 & 7.5 & 2.0 & 7.2 & 5.6 & 0.0 & 2.0 & -6.8 & 0.8 & -5.0 \\
\hline 17 & -5.3 & -7.1 & -7.2 & -9.6 & -7.7 & -9.1 & -11.5 & 11.2 & 7.1 & 6.7 & 1.1 & 6.4 & 4.8 & -0.8 & 1.2 & -7.7 & 0.0 & -5.8 \\
\hline 4 & 4.3 & 2.5 & 2.4 & 0.0 & 1.9 & 0.5 & -1.9 & 20.8 & 16.6 & 16.3 & 10.7 & 16.0 & 14.4 & 8.8 & 10.8 & 1.9 & 9.6 & 3.8 \\
\hline 11 & -6.4 & -8.2 & -8.3 & -10.7 & -8.9 & -10.2 & -12.6 & 10.1 & 5.9 & 5.6 & 0.0 & 5.3 & 3.7 & -2.0 & 0.1 & -8.8 & -1.1 & -6.9 \\
\hline
\end{tabular}

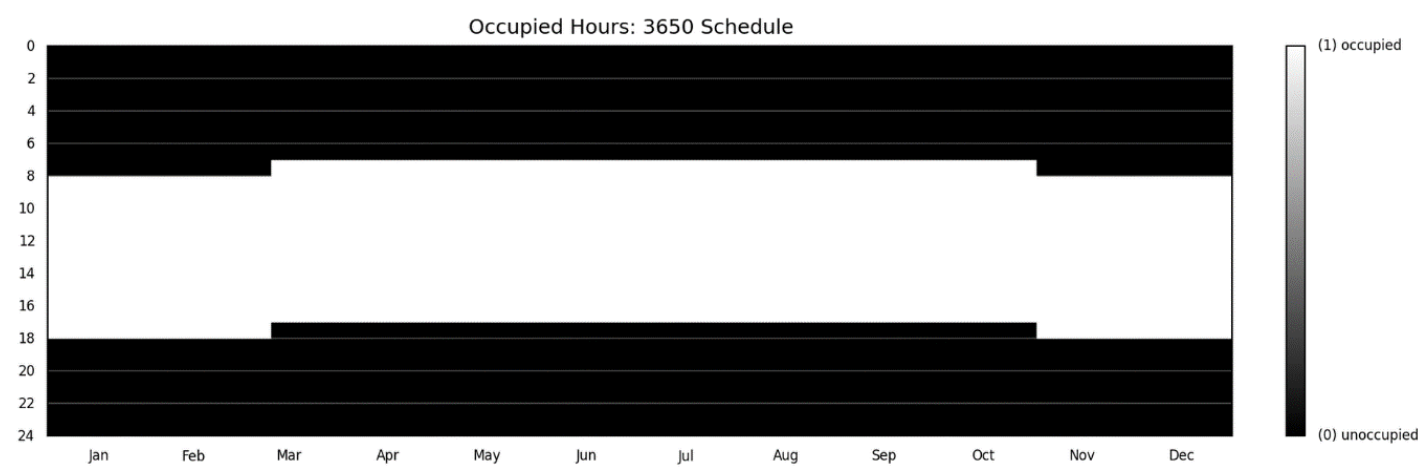

Figure A1. Occupancy profile.

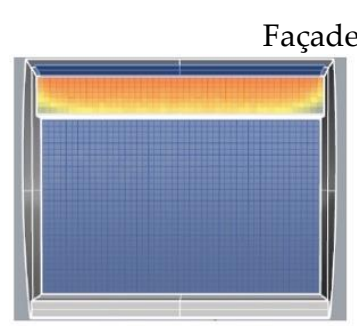

$\mathrm{DA}_{500}=0,07 \%$

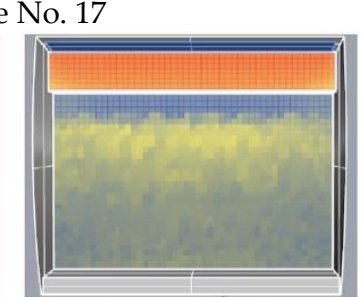

$\mathrm{CDA}_{500}=20,57 \%$

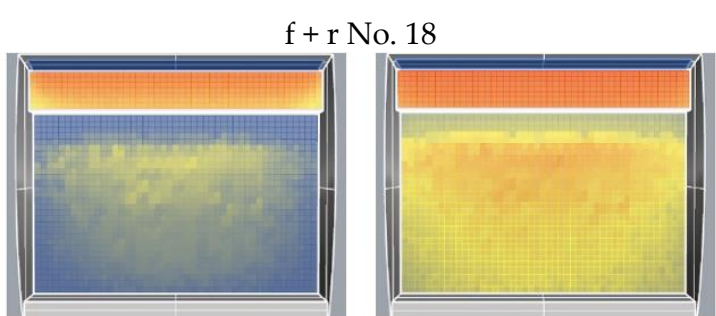

$\mathrm{DA}_{500}=13,60 \%$

$\mathrm{CDA}_{500}=50,12 \%$

Figure A2. Spatial distribution of annual daylight indicators for scenarios with target illuminance $500 \mathrm{~lx}$ (Nos. 17 and 18). 


\section{References}

1. Haase, W.; Klaus, T.; Knubben, E.; Mielert, F.; Neuhäuser, S.; Schmid, F.; Sobek, W. Adaptive Mehrlagige Textile Gebäudehüllen Mit Anl. 1. Recherchebericht: Beispiele zur Konstruktiven Ausführung Mehrlagiger Gedämmter Membranbauwerken Simulationstool für Mehrlagige Aufbauten; Fraunhofer IRB Verlag: Stuttgart, Germany, 2011; ISBN 9783816786061.

2. Hall in Odate, Japan, 06/1998 DETAIL. 1998, p. 957. Available online: https://inspiration.detail.de/hall-inodate-japan-109315.html (accessed on 18 August 2018).

3. Lang, W.; Rampp, T.; Ebert, H.-P. The Energy Efficiency Center of the Center for Applied Energy Research Würzburg. In Proceedings of the 30th International Plea Conference, Ahmedabad, India, 16-18 December 2014.

4. Lienhard, J.; Knippers, J.; Cremers, J.; Gabler, M. Atlas Kunststoff + Membranen; DETAIL Kon.; DE GRUYTER: München, Germany, 2010; ISBN 9783955530037.

5. Knissel, J. Energieeffiziente Büro- und Verwaltungsgebäude; IWU: Darmstadt, Germany, 1999.

6. EIA Commercial Buildings Energy Consumption Survey (CBECS 2012). Available online: https:/ / www.eia. gov / consumption/commercial/reports/2012/lighting/ (accessed on 4 May 2018).

7. Beusker, E.; Stoy, C.; Pollalis, S.N. Estimation model and benchmarks for heating energy consumption of schools and sport facilities in Germany. Build. Environ. 2012, 49, 324-335. [CrossRef]

8. Zeine, C.; Gebhardt, M.; Bockting, B.; Mantai, A.; Ping, J. Verbrauchskennwerte 2005: Energie- und Wasserverbrauchskennwerte in der Bundesrepublik Deutschland. Available online: http://kw2003.de/ index.php?option=com_kennwerte (accessed on 11 May 2018).

9. Karopka, L.; Klöffel, A.; Therburg, I.; Kopetzky, D.R.; Weber, D.T.; Kunkel, S.; Schettler-Köhler, H.-P.; Vilz, A. Benchmarks für die Energieeffizienz von Nichtwohngebäuden: Vergleichswerte für Energieausweise; Bundesministerium für Verkehr, Bau und Stadtentwicklung (BMVBS) and Bundesinstitut für Bau-, Stadtund Raumforschung (BBSR): Bonn, Germany, 2009.

10. CIBSE. Energy Consumption Guide 78: Energy Use in Sports and Recreation Buildings; CIBSE: London, UK, 2001.

11. Lowry, G. Energy saving claims for lighting controls in commercial buildings. Energy Build. 2016, 133, 489-497. [CrossRef]

12. Krarti, M.; Erickson, P.M.; Hillman, T.C. A simplified method to estimate energy savings of artificial lighting use from daylighting. Build. Environ. 2005, 40,747-754. [CrossRef]

13. Ihm, P.; Nemri, A.; Krarti, M. Estimation of lighting energy savings from daylighting. Build. Environ. 2009, 44, 509-514. [CrossRef]

14. Marks, F.M. Letter to the Editors: Lighting for Different Healthcare Settings. HERD Health Environ. Res. Des. J. 2013, 6, 166-168. [CrossRef]

15. Plympton, P.; Conway, S.; Epstein, K. Daylighting in Schools: Improving Student Performance and Health at a Price Schools Can Afford. Presented at the American Solar Energy Society Conference, Madison, WI, USA, 16 June 2000.

16. Kontadakis, A.; Tsangrassoulis, A.; Doulos, L.; Zerefos, S. A Review of Light Shelf Designs for Daylit Environments. Sustainability 2017, 10, 71. [CrossRef]

17. Matusiak, B.S. Glare from a translucent façade, evaluation with an experimental method. Sol. Energy 2013, 97, 230-237. [CrossRef]

18. Pagliolico, S.L.; Lo, V.R.M.; Torta, A.; Giraud, M.; Canonico, F.; Ligi, L. A preliminary study on light transmittance properties of translucent concrete panels with coarse waste glass inclusions. Energy Procedia 2015, 78, 1811-1816. [CrossRef]

19. Rosso, F.; Pisello, A.L.; Cotana, F.; Ferrero, M. Cool, Translucent Natural Envelope: Thermal-optics Characteristics Experimental Assessment and Thermal-energy and Day Lighting Analysis. Energy Procedia 2017, 111, 578-587. [CrossRef]

20. Souayfane, F.; Henry, P.; Fardoun, F. Thermal behavior of a translucent superinsulated latent heat energy storage wall in summertime. Appl. Energy 2018, 217, 390-408. [CrossRef]

21. Ahuja, A.; Mosalam, K.M. Evaluating energy consumption saving from translucent concrete building envelope. Energy Build. 2017, 153, 448-460. [CrossRef]

22. Vu, N.H.; Shin, S. A large scale daylighting system based on a stepped thickness waveguide. Energies 2016, 9, 71. [CrossRef] 
23. Ullah, I.; Whang, A. Development of Optical Fiber-Based Daylighting System and Its Comparison. Energies 2015, 8, 7185-7201. [CrossRef]

24. Genswein, M.; Eicker, U. Ressourceneffizientes Gebäude für die Welt von Übermorgen: Forschungsprojekt REG II: Projektbericht; Hochschule für Technik Stuttgart: Stuttgart, Germany, 2016.

25. Shishegar, N.; Boubekri, M. Quantifying electrical energy savings in offices through installing daylight responsive control systems in hot climates. Energy Build. 2017, 153, 87-98. [CrossRef]

26. Li, D.H.W.; Cheung, A.C.K.; Chow, S.K.H.; Lee, E.W.M. Study of daylight data and lighting energy savings for atrium corridors with lighting dimming controls. Energy Build. 2014, 72, 457-464. [CrossRef]

27. Chow, S.K.H.; Li, D.H.W.; Lee, E.W.M.; Lam, J.C. Analysis and prediction of daylighting and energy performance in atrium spaces using daylight-linked lighting controls. Appl. Energy 2013, 112, 1016-1024. [CrossRef]

28. Roisin, B.; Bodart, M.; Deneyer, A.; D'Herdt, P. Lighting energy savings in offices using different control systems and their real consumption. Energy Build. 2008, 40, 514-523. [CrossRef]

29. Fernandes, L.L.; Lee, E.S.; DiBartolomeo, D.L.; McNeil, A. Monitored lighting energy savings from dimmable lighting controls in The New York Times Headquarters Building. Energy Build. 2014, 68, 498-514. [CrossRef]

30. Rizzo, F.; Ricciardelli, F. Design pressure coefficients for circular and elliptical plan structures with hyperbolic paraboloid roof. Eng. Struct. 2017, 139, 153-169. [CrossRef]

31. Rizzo, F.; Zazzini, P. Shape Dependence of Acoustic Performances of Buildings with a Hyperbolic Paraboloid Cable Net Membrane Roof. Acoust. Aust. 2017, 45, 421-443. [CrossRef]

32. FürthWiki e. V.--Verein für freies Wissen und Stadtgeschichte; Julius-Hirsch-Sportzentrum. Available online: https:/ / www.fuerthwiki.de/wiki/index.php/Julius-Hirsch-Sportzentrum (accessed on 19 April 2018).

33. Fab_architekten Achitect Competition. Available online: http://www.fab-architekten.de/fuerth.html (accessed on 19 April 2018).

34. Cremers, J.; Palla, N.; Buck, D.; Beck, A.; Biesinger, A.; Brodkorb, S. Analysis of a Translucent Insulated Triple-layer Membrane Roof for a Sport Centre in Germany. Procedia Eng. 2016, 155, 38-46. [CrossRef]

35. Mardaljevic, J.; Heschong, L.; Lee, E. Daylight metrics and energy savings. Light. Res. Technol. 2009, 41, 261-283. [CrossRef]

36. Reinhart, C.F.; Mardaljevic, J.; Rogers, Z. Dynamic daylight performance metrics for sustainable building design. LEUKOS-J. Illum. Eng. Soc. N. Am. 2006, 3, 7-31. [CrossRef]

37. Rogers, Z.; Goldman, D. Daylighting Metric Development Using Daylight Autonomy Calculations in the Sensor Placement Optimization Tool; Architectural Energy Corporation: Boulder, CO, USA, 2006; pp. 1-52. 